\title{
KORELASI BUDAYA PERKEBUNAN DAN FENOMENA “BURUH BORONG” PERKEBUNAN SAWIT DI KALI MANTAN BARAT
}

\section{PLANTATI ON CULTURAL CORELATI ON AND THE PHENOMENA OF “BURUH BORONG" ON PALM OI L PLANTATI ON I N WEST KALI MANTAN}

\author{
Nugroho Trisnu Brata \\ Fakultas I Imu Sosial, Universitas Negeri Semarang \\ Email: trisnubrata@yahoo.com
}

Diterima tanggal: 19/06/2012, Dikembalikan untuk revisi tanggal:02/07/2012, Disetujui tanggal: 29/08/2012

\begin{abstract}
Abstrak: Tujuan penulisan risalah artikel ini mengkaji fenomena kebudayaan masyarakat yang kemudian dihubungkan dengan keberadaan pekerja "buruh borong" di area perkebunan sawit. Setiap kebudayaan masyarakat diasumsikan memiliki karakter yang tergantung pada konteks spasial (tempat) maupun temporal (waktu). Salah satu aspek kebudayaan adalah nilai budaya. Permasalahan dalam penelitian ini adalah, "Nilai apa saja yang menjadi penuntun komunitas buruh borong (BB) dalam bekerja di area perkebunan sawit?". Metode penelitian yang digunakan adalah metode penelitian kualitatif. Penelitian dilakukan selama satu bulan di lapangan. Hasil penelitian menunjukkan bahwa orang-orang yang bekerja di perkebunan sawit latar belakangnya berbeda-beda. Nilai-nilai budaya yang menjadi bagian dari kebudayaan ternyata juga muncul dalam fenomena para pekerja perkebunan. Konsep nilai menjadi konsep kunci dalam teori tindakan (theory of action). Bekerja sebagai fenomena sosial pun bisa diletakkan di atas kerangka pikir orientasi nilai maupun teori tindakan. Pada kelompok pekerja "buruh borong" terdapat nilai saling percaya, nilai kebersamaan, nilai perlawanan kultural, nilai religi, relasi patron-klien, dan nilai ketekunan.
\end{abstract}

Kata kunci: buruh borong, perkebunan, sawit, nilai, dan fenomena kebudayaan

\begin{abstract}
This essay aims at analyzing a connection of a community cultural phenomenon in oil palm plantation area and the existence of 'buruh borong'. Each community cultural phenomenon is assumed to have characteristic which depend on both spatial and temporal context. One of cultural aspects is cultural value. The problem scope of this research is cultural value which guide the buruh borong (BB) in oil palm plantation area. Qualitative method is applied on the research. The research lasts for a month on field. The result of the research shows that the people working in oil palm plantation have various background. Cultural values as parts of culture appear in the phenomenon of plantation workers. The concept of value is the main concept in theory of action. Working as a social phenomenon is also done in the framework of value orientation and theory of action. Among the workers of buruh borong, there are values of trusting each other, togetherness, cultural defence, religion, patron-client relation, and diligence.
\end{abstract}

Keywords: buruh borong, plantation, palm oil, value, and culture phenomena

\section{Pendahuluan}

Lokasi penelitian ini di area perkebunan kelapa sawit milik PTPN XIII yang berada di Kecamatan Meliau, Kabupaten Sanggau, Provinsi Kalimantan Barat. Untuk mencapai lokasi penelitian, dapat ditempuh lebih kurang $200 \mathrm{Km}$ dari Kota Pontianak baik melalui transportasi Sungai Kapuas maupun transportasi darat.
Di area perkebunan kelapa sawit tersebut terdapat banyak orang yang melakukan aktivitas bekerja, dan artikel ini berusaha mengkaji fenomena bekerja di sebuah perkebunan kelapa sawit di Kecamatan Meliau, Kabupaten Sanggau, Provinsi Kalimantan Barat. Di mana orang-orang yang bekerja di perkebunan kelapa sawit milik negara (Badan Usaha Milik Negara/BUMN) tersebut 
bisa dikelompokkan ke dalam empat kategori, yaitu karyawan tetap, karyawan perjanjian kerja waktu tertentu (PKWT), buruh lepas (BL), dan buruh borong (BB). Kebun kelapa sawit tersebut dipimpin oleh seorang manajer (dulu disebut administratur disingkat adm) dengan dibantu oleh asisten kepala, asisten, mandor satu, mandor, dan krani. Kebun tersebut membawahi tujuh afdeling, setiap afdeling dipimpin oleh seorang asisten (dulu disebut sinder).

Menurut Personalia Umum dan Humas PTPN XIII Kebun Sungai Dekan (2001), struktur kerja selengkapnya adalah sebagai berikut. Di bawah manajer (administratur/adm) terdapat 2 askep (asisten kepala), yaitu askep yang membawahi Rayon B (afdeling 1, afdeling 2, afdeling 3, dan afdeling 7), dan askep yang membawahi Rayon $A$ (afdeling 4, afdeling 5, afdeling 6). Di bawah askep terdapat asisten-asisten yang memimpin 7 afdeling tersebut, asisten TU (tanam ulang), asisten PU (pekerjaan umum), dan asisten rumah sakit. Mereka yang berada pada jajaran manajer, askep, dan asisten disebut sebagai "pimpinan kebun", dan semua bertempat tinggal di perumahan emplasemen yang merupakan rumah milik perusahaan.

Di bawah asisten terdapat "mandor satu" yang bertempat tinggal di perumahan afdeling. Di bawah mandor satu terdapat krani, dan di bawah krani terdapat "mandor-mandor". Di bawah mandor yang merupakan lapis paling bawah terdapat pekerja yang terdiri atas karyawan tetap, karyawan PKWT, dan BL.

Buruh borong (BB) tidak menjadi bagian di dalam struktur kerja perkebunan. BB bekerja dengan sistem borongan, yaitu jika pekerjaan sudah selesai dikerjakan, maka upah segera diterimakan oleh pemborong atau mandor borong kepada pekerja/buruh. Keberadaan BB di perkebunan kelapa sawit dibawa oleh pemborong pekerjaan/kontraktor, dan menjadi tanggung jawab mereka. BB bekerja secara borongan sesuai order pekerjaan yang diperintahkan oleh pemborong pekerjaan atau oleh mandor borong yang menjadi kepanjangan tangan pemborong pekerjaan. Surat Perjanjian Kerja (SPK) sebagai legitimasi pelaksanaan proyek pekerjaan di pegang oleh pemborong pekerjaan/kontraktor dan pihak PTPN XIII. Jika pekerjaan telah selesai dikerjakan dan upah telah dibayarkan, maka BB bebas untuk mencari pekerjaan di tempat lain sesuai dengan kenginannya atau pekerjaan yang dia anggap baik.

Apabila setiap orang yang bekerja memiliki penilaian terhadap pekerjaannya, maka kemudian muncul pertanyaan nilai seperti apa itu. Dari deskripsi ini kemudian muncul permasalahan riset, “Nilai apa saja yang menjadi penuntun komunitas buruh borong (BB) dalam bekerja di area perkebunan sawit?".

Tujuan penelitian ini dimaksudkan untuk menjawab permasalahan tentang nilai-nilai bekerja pada komunitas BB di perkebunan kelapa sawit, bahwa upah (wage) bukan satu-satunya aspek penting bagi orang bekerja.

\section{Kajian Literatur}

Zurinani (2010) pernah melakukan penelitian tentang fenomena bekerja di perkebunan kelapa sawit PTPN XIII tersebut. Menurut Zurinani (2010), bekerja menjadi karyawan tetap di perkebunan tidak jauh berbeda dengan bekerja menjadi pegawai negeri sipil. Kedua jenis pekerjaan ini sama-sama bergaji bulanan dan mendapat pensiun. Bahkan karyawan tetap di perkebunan sawit mendapat rumah dinas selama bekerja di perkebunan tersebut. Di antara para perempuan yang telah menyandang status karyawan ada pula yang masih berstatus sebagai buruh lepas di perkebunan sawit. Berbeda dengan karyawan, buruh lepas hanya mengandalkan gaji yang dihitung harian. Kadang-kadang tiga bulan sekali gaji buruh lepas baru diberikan. Sungguh dua kehidupan yang berbeda antara karyawan dan buruh lepas. Banyak buruh lepas yang berharap nantinya akan diangkat menjadi karyawan. Lebih lanjut Zurinani (2010) menyatakan bahwa para buruh lepas sering mendapatkan tempat yang lebih sulit daripada medan kerja yang dikerjakan oleh karyawan tetap. Walau demikian mereka tetap mau bekerja di perkebunan, karena tidak ada lagi pekerjaan lain yang mereka kerjakan.

Struktur kerja di perkebunan sawit mirip dengan struktur kerja di perkebunan teh sebagaimana diungkapkan oleh Syahrizal (2006). Menurut Syahrizal (2006), stuktur kerja masyarakat perkebunan teh PT Mitra Kerinci di Sumatera Barat adalah sebagai berikut. Site 
manajer bertugas memimpin pengolahan kebun mulai dari penanaman sampai menjual hasil produksi. Site manajer membawahi pembantu utama yang terdiri atas tiga strata, yaitu Asisten Kepala, Kepala Dinas Pengolahan dan Teknik, dan Kepala Tata Usaha. Asisten kepala bertugas mengawasi hal-hal yang berkaitan dengan tanaman mulai dari penanaman, pemeliharaan dan pemetikan. Kepala dinas pengolahan dan teknik bertugas pada pengolahan teh yang telah dipetik sampai siap dijual, sedangkan kepala tata usaha bertugas di bidang administrasi.

Sering kali dalam mencari pekerjaan atau menciptakan lapangan pekerjaan orang memilihmilih pekerjaan apa yang sesuai dengan keinginannya, kemampuannya, atau kondisi sosial budaya masyarakatnya. Studi mengenai bekerja yang dilakukan oleh Wallman (1979) menyebutkan bahwa manusia bekerja itu terkait dengan sembilan dimensi. Satu dari sembilan dimensi itu adalah dimensi value, bahwa value (nilai) menurut Wallman bisa menentukan posisi sosial, pribadi, atau tingkatan ekonomi orang yang bekerja. Dalam pandangan Wallman, nilai itu dibutuhkan oleh masyarakat, individu atau aspek ekonomi yang mana nilai itu ditentukan oleh kriteria moral atau material.

Untuk mengkaji fenomena masyarakat yang bekerja di area perkebunan kelapa sawit ini fokus kajiannya pada dimensi value (nilai) yang melekat dengan makna orang bekerja seperti dikemukakan oleh Wallman di muka. Wallman (1979) juga menyatakan bahwa tidak ada nilai yang otonom, nilai dalam bekerja tentu tergantung pada elemen-elemen lain dalam sistem kerja tersebut. Sejalan dengan Wallman, Marzali (2005) juga mengemukakan tentang apa itu value atau nilai.

Marzali (2005) menyatakan bahwa ilmuwan yang pada awalnya mendalami konsep nilai (value) adalah Clyde Kluckhohn, seorang pakar antropologi dan suami dari Florence R. Kluckhon. Konsep nilai ini kemudian menginspirasi munculnya orientasi nilai (value orientation) yang dikembangkan oleh Florence R. Kluckhohn dan Fred L. Strodtbeck (1961) dalam buku mereka yang berjudul Variations in Value Orientations. Konsep nilai menjadi konsep yang pokok dalam konteks "theory of action" yang dikembangkan oleh para ilmuwan sosial di Harvard University, yaitu Talcott Parsons, Edward Shils, Gordon Allport, Henry Muray, dan Clyde Kluckhohn.

Apa yang disampaikan oleh Marzali tersebut menggambarkan bahwa nilai merupakan sebuah konsep yang cukup penting dalam ilmu sosial. Konsep nilai bisa menginisiasi munculnya konsep orientasi nilai. Konsep nilai juga menjadi konsep kunci dalam teori tindakan (theory of action). Bekerja sebagai fenomena sosial pun bisa diletakkan di atas kerangka pikir orientasi nilai maupun teori tindakan. Lebih jauh lagi Marzali (2005) memaparkan definisi nilai dengan mengutip Clyde Kluckhohn dkk., yaitu "Sebuah nilai adalah sebuah konsepsi, eksplisit atau implisit, yang khas milik seorang individu atau suatu kelompok, tentang yang seharusnya diinginkan yang mempengaruhi pilihan yang tersedia dari bentuk-bentuk, cara-cara, dan tujuan-tujuan tindakan". Menurut Marzali dari definisi di muka terdapat kata kunci nilai yang artinya konsepsi tentang 'hal yang seharusnya diinginkan', yang harus dibedakan dengan 'hal yang diinginkan'. Nilai bersifat abstrak, nilai hanya bisa disimpulkan dan ditafsirkan dari ucapan, perbuatan, dan materi yang dibuat manusia. Ucapan, perbuatan, dan materi adalah manifestasi dari nilai.

Tidak banyak warga masyarakat yang dapat dengan eksplisit dan tegas mengatakan nilai-nilai budaya yang mereka miliki dan ikuti, walaupun sehari-hari mereka menggunakan nilai-nilai tersebut untuk menghadapi lingkungan mereka. Meskipun demikian, adanya nilai-nilai budaya ini bisa diketahui lewat unsur-unsur budaya tertentu (Ahimsa-Putra, 2009).

Dari pokok pikiran di atas dapat disintesiskan bahwa bila seseorang bekerja (termasuk BB), maka dalam aktivitas bekerja tersebut melekat adanya nilai, yaitu nilai bekerja. Nilai bekerja adalah sesuatu yang seharusnya diinginkan atau seharusnya dilakukan.

\section{Metodologi}

Metode penelitian yang digunakan adalah metode kualitatif. Metode kualitatif dipilih karena sifat dari masalah yang diteliti berusaha mengungkap makna bekerja dari sudut pandang si pelaku. Menurut Strauss \& Corbin (2003) tentang mengapa penelitian kualitatif dipilih, selain alasan 
kemantapan peneliti berdasar pengalamannya meneliti, alasan lain adalah sifat dari masalah yang diteliti. Metode kualitatif dapat digunakan untuk mengungkap dan memahami sesuatu di balik fenomena yang sedikit pun belum diketahui, atau mengungkap sesuatu yang baru sedikit diketahui. Metode ini dapat mengungkap fenomena yang sulit diungkap oleh metode kuantitatif.

Penelitian ini bukan penelitian kuantitatif melainkan penelitian kualitatif. Sebagaimana dinyatakan oleh Hagul dkk (1980) "bahwa dalam penelitian kuantitatif peneliti perlu menentukan variabel-variabel penelitian dan selanjutnya merumuskan hipotesis berdasarkan hubungan antarvariabel". Karena penelitian ini menggunakan metode kualitatif, sehingga tidak diperlukan adanya variabel, hipotesis, dan hubungan antarvariabel.

Lokasi penelitian dilakukan pada perkebunan kelapa sawit yang berada di bawah struktur perusahaan PT Perkebunan Nusantara XIII (PTPN XIII) tepatnya di Kebun Sungai Dekan yang berada dalam wilayah Kecamatan Meliau, Kabupaten Sanggau, Provinsi Kalimantan Barat. Waktu penelitian selama 1 bulan di lapangan, yaitu pada bulan J uli 2011.

Pengambilan data dilakukan dengan observasi, partisipasi observasi, dan wawancara mendalam. Guna kemudahan berinteraksi dengan para informan, penulis tinggal di lokasi penelitian, yaitu di emplasemen (keluarga Pak Sularno) selama 20 hari dan di afdeling 3 (keluarga Pak Parno) selama 10 hari. Penulis terlebih dahulu berkenalan dan berusaha menjadi teman terhadap masyarakat tempat penulis melakukan penelitian, dengan harapan data bisa didapatkan dengan mudah jika mereka sudah saling mengenal dan saling percaya.

\section{Hasil dan Pembahasan \\ J enis Pekerjaan dan Daerah Asal}

Sebagaimana telah ditulis di muka bahwa orangorang yang bekerja di perkebunan kelapa sawit bisa dikelompokkan ke dalam karyawan tetap, karyawan perjanjian kerja waktu tertentu (Karyawan PKWT), buruh lepas (BL), dan buruh orong (BB). Fasilitas yang diperoleh bagi karyawan tetap, yakni semua anggota keluarganya mendapat jaminan berobat, asuransi dari PTPN XIII, mendapat uang pensiun, dan mendapat hak cuti (status mereka mirip dengan PNS). Mereka terdiri atas karyawan tetap “kantoran”, yaitu bekerja di kantor perkebunan, dan karyawan tetap "lapangan" (contohnya Sularno dan istrinya awalnya karyawan tetap lapangan/pemanen, kemudian dimutasi menjadi karyawan tetap di Wisma Tengkawang). Berbeda dengan karyawan PKWT di mana yang mendapat fasilitas dari PTPN hanya anggota keluarga ( 1 orang) yang bekerja di PTPN saja, anggota keluarga yang lain tidak mendapatkan failitas seperti halnya karyawan tetap. Kontrak kerja karyawan PKWT berlangsung selama 2 tahun, setelah itu bisa diperpanjang dengan kontrak baru selama 2 tahun lagi begitu seterusnya, atau putus hubungan kerja. Sedangkan BL tidak mendapat fasilitas seperti karyawan tetap atau karyawan PKWT, mereka mendapat upah tiap bulan. BL umumnya adalah anggota keluarga karyawan tetap atau karyawan PKWT yang ikut tinggal di rumah-rumah perkebunan. Bisa jadi mereka adalah istri, suami, anak, menantu, atau kerabat dari karyawan. BL umumnya terdiri atas orang-orang dari perkampungan penduduk lokal di sekitar area perkebunan kelapa sawit, seperti dari kampung Dekan Putih, Kuala Buayan, Sungai Ale, Penyelimau, atau Sungai Tapang.

Sejak perkebunan sawit ini dibuka awal tahun 1980-an status para pekerja umumnya adalah pekerja kontrak yang kemudian dilanjutkan menjadi karyawan tetap. Pasangan suami-istri, keduanya bisa menjadi karyawan tetap di perkebunan BUMN tersebut. Model karyawan PKWT mulai ada sejak Jusuf Kalla menjadi Wakil Presiden (sekitar tahun 2004, sebagai implementasi atas UU No.13 Tahun 2003 tentang tenaga kerja). Sebelumnya yang ada hanya karyawan tetap. Karyawan tetap dan karyawan PKWT menerima gaji setiap hari Kamis setelah minggu keempat, sedangkan BL menerima upah setelah jadwal gaji karyawan tetap dan karyawan PKWT diterimakan.

Berbeda dengan karyawan tetap, karyawan PKWT dan BL yang memiliki hubungan langsung secara administrasi dengan birokrasi perusahaan perkebunan, maka BB tidak memiliki hubungan langsung dengan birokrasi perusahaan 
perkebunan. BB bekerja kepada kontraktor (pihak ke-3) dan kontraktorlah yang berhubungan langsung dengan perusahaan perkebunan. Kontraktor adalah orang yang memiliki CV pengerah jasa tenaga kerja (PJTK), dan memiliki badan hukum. Kontraktor menjadi jembatan antara BB dengan perusahaan. Kadang kala kontraktor sering dipinjam "benderanya" oleh "orang dalam" perkebunan untuk mengerjakan proyek pekerjaan tertentu, kemudian kontraktor tersebut mendapatkan fee atau komisi dari "orang dalam" tadi. Cara ini untuk mengantisipasi jika ada pemeriksaan oleh BPK agar tidak salah secara administrasi. Kontraktor pemilik CV yang sering menjadi rekanan di area perkebunan antara lain yakni Ajid yang tinggal di Meliau, Ameo pemilik CV Gunung Mas tinggal di Kampung Pelampung, dan Lele yang tinggal di Meliau. Ketiganya merupakan warga keturunan China. Para kontraktor ini ketika menggarap pekerjaan biasanya berpartner dengan mandor satu di masing-masing afdeling.

Jenis pekerjaan yang dilakukan oleh BB umumnya membuat "tapak kuda" untuk replanting, membangun rumah, membangun jalan, dan membangun jembatan. Secara lebih jelas pekerjaan yang dilakukan oleh BB di perkebunan sawit ialah sebagai berikut.

\section{Latar Membuat Tapak}

Membuat "tapak kuda" dan "piringan" pada daerah miring, atau "piringan" saja pada daerah datar BB akan dibayar sesuai jumlah tapak kuda atau piringan yang telah dibuat. Fungsi utama piringan dan tapak yakni sebagai tempat menanam bibit kelapa sawit. Disebut tapak kuda karena bentuknya seperti tapal besi yang biasa dipasang di telapak kaki kuda. Misalnya, jika BB dalam satu hari bisa membuat 5 tapak, maka pendapatan dia/upah 5 tapak kali Rp 17.000,untuk piringan yang mudah. Sedangkan untuk tapak kuda dan piringan yang sulit karena tanahnya miring maka upah untuk BB juga menjadi lebih mahal. Besar kecilnya upah bergantung dari tingkat kesulitan membuat tapak.

Tapak kuda dibuat untuk daerah yang miring seperti lereng atau pinggir parit agar pupuk dan air tidak langsung hilang dibawa air hujan. Untuk daerah cekung seperti parit atau rawa dibuat "tapak timbun" agar air tidak menggenang. Pohon kelapa sawit merupakan jenis tanaman yang tidak membutuhkan banyak air, sehingga tidak boleh ada air yang menggenang. Sebelum BB bekerja membuat tapak kuda, ada pekerja lain (yang disebut manceng) yakni menancapkan batangbatang bambu yang ujungnya dicat warna merah atau putih secara garis lurus berderet-deret di lokasi replanting. Cat merah pada ujung bambu yang ditancapkan di tanah dalam proses replanting artinya pertanda agar di lokasi penancapan bambu tersebut harus dibuat tapak kuda oleh BB. Jika di ujung bambu tidak terdapat tanda cat merah atau putih tetapi BB membuat tapak kuda di tempat itu, maka dia tidak mendapat upah sebab tidak ada tanda perintah membuat tapak, tapi cukup dibuat piringan atau lingkaran di sekitar bambu. Jari-jari tapak kuda, tapak timbun, atau piringan lebih kurang sama, yaitu 2,40 meter. Agar gawangan (jarak antar pohon) dapat seragam dan posisi baris lurus maka harus dibuat dengan menggunakan bantuan benang panjang dan dikerjakan oleh beberapa orang.

Tenaga yang melakukan "manceng" untuk memasang batang-batang bambu berbeda dengan tenaga kerja yang membuat tapak. Bagi yang tidak terbiasa, pekerjaan membuat tapak cukup sulit dan cukup berat. Biasanya karyawan tetap di perkebunan umumnya tidak sanggup membuat tapak kuda atau tapak timbun. Apalagi jika lokasinya tidak teduh atau rimbun oleh pepohonan sawit yang lama, maka sinar matahari akan sangat panas menyengat badan. Karena pekerjaan membuat tapak (napak) berat maka biasanya dilakukan secara borongan dengan mendatangkan buruh borong (BB) dari luar perkebunan yang sanggup membuat tapak. Sularno yang waktu itu karyawan tetap di afdeling 2 dengan pekerjaan "pemanen" buah sawit, pernah melakukan kerja tambahan membuat tapak kuda. Dia berhasil membuat 3 sampai 4 tapak kuda, tetapi pada malam harinya tubuh terasa sangat lelah sampai-sampai dia mengalami demam (panas dingin) dan pegal-pegal. Sejak saat itu dia kapok dan tidak mau lagi membuat tapak kuda.

Pak Ndhole hari itu melanjutkan membuat tapak kuda yang sudah dia kerjakan sejak beberapa waktu yang lalu. Di dekat Ndhole bekerja, juga ada Sukir yang juga sedang membuat tapak. 
Kala istirahat Sukir biasanya menghisap dua batang rokok. Di afdeling 3 Kebun Sungai Dekan saat ini terdapat 17 buruh borong yang membuat tapak, dan 15 orang buruh borong yang membuat rumah. Selama bekerja membuat tapak, Sukir menginap di sebuah rumah kosong di afdeling 3 dekat masjid, di depan rumah Pak Kaum. Di rumah tersebut ia menginap bersama dengan Munaji dari Ponorogo, dan Sarjan dari Blora. Sukir mulai bekerja sebelum bulan Puasa tahun 2010 hingga setelah Lebaran Haji tahun yang sama, baru kemudian dia pulang ke Blora. Ada juga Mujiono (30 th), dan Triono (27 th). Mujiono berasal dari Candiroto, Temanggung, Jawa Tengah. Dia mengikuti program transmigrasi di lokasi Sei Radak Kabupaten Kubu Raya (pemekaran dari Kabupaten Mempawah), Kalimantan Barat.

\section{Latar Membangun Rumah}

Mulanya rumah-rumah karyawan di perkebunan sawit Sungai Dekan terbuat dari kayu. Pertimbangannya kala itu ialah bahwa bahan baku pembuatan rumah tersedia melimpah, karena saat perkebunan mulai dibuka tahun 1980-an sebagian masih berupa hutan lebat dengan pepohonan yang besar yang kemudian digergaj $\mathrm{i}$ menjadi papan kayu. Setelah rumah-rumah kayu tersebut berusia 30-an tahun, sebagian mulai rusak, selanjutnya mulai direhab oleh perusahaan, yang kemudian dibangun rumah baru terbuat dari tembok semen, bukan oleh penghuni rumah karena rumah-rumah tersebut statusnya milik perusahaan.

Suradi merupakan karyawan tetap dengan tugas mandor tanam ulang (mandor TU) juga nyambi menjadi kontraktor membuat tapak. Selain itu, Suradi juga mendatangkan BB dari daerah lain untuk membangun rumah. Para BB yang membangun rumah di afdeling 3 umumnya menempati rumah kosong di sebelah rumahnya Suwaji. BB yang sedang membangun rumah di afdeling 3 yaitu Munaji (tua), dan Taryono serta dibantu 6 orang lain sehingga jumlahnya 8 orang. Mereka datang dari Desa Klopoduwur, Kecamatan Banjarrejo, Kabupaten Blora Jawa Tengah secara rombongan. Orang kunci yang membawa mereka ke afdeling 3 bernama Sutarno. Dia merupakan pemborong (kontraktor) tenaga kerja dari Blora dan ikut tinggal di afdeling 3 bersama-sama dengan BB dalam membangun rumah. Kasarnya, Sutarno adalah pemborong tenaga kerja tidak termasuk material. Sebab seluruh material bahan bangunan rumah disediakan oleh kontraktor pemilik proyek, yaitu Pak Ajid (pemilik CV Aneka) dari Meliau. Ajid mensubkontrakkan urusan BB untuk proyek pembangunan rumah di afdeling 3 ini kepada Suradi. Selanjutnya, Suradi menghubungi Sutarno di Blora, Jawa Tengah untuk membawa sejumlah tenaga BB ke afdeling 3 . Satu rumah harga borongannya untuk tenaga kerja (BB) saja Rp 20 juta. Karena di afdeling 3 terdapat 3 rumah yang sedang dibangun, sehingga nilai borongan tenaganya ialah $3 \times \mathrm{Rp} 20$ juta $=\mathrm{Rp} 60$ juta. Dari nilai Rp 60 juta itu setelah dipotong panjar dan bon makan minum hari-hari efektif selama bekerja, sisanya menjadi upah bersih yang diterima oleh para pekerja. Menurut Pak Munaji (tua) jam kerja BB tidak kaku, tetapi biasanya antara pukul 07.00 pagi hingga magrib (pukul 18.00). Beratnya pekerjaan membangun rumah ini juga dibenarkan oleh Suradi. Menurut Suradi menjadi BB membangun rumah merupakan pekerjaan yang berat karena mengandalkan fisik dan bekerja kadang mulai dari pukul 06.00 dan berhenti hingga pukul 18.00. Semakin cepat menyelesaikan pekerjaan borongan menjadi semakin baik, artinya waktu bisa singkat dan tenaga bisa dihemat serta upah cepat bisa diterima, dan selanjutnya bisa segera mencari pekerjaaan borongan di tempat lain.

\section{Latar Membangun J alan}

Di warung kopi Pak Kaum di afdeling 3 penulis pernah mewawancarai dua BB bernama Edi (17 tahun) dan Memed (18 tahun) yang sedang membangun jalan di afdeling 3. Hari itu, mereka sedang tidak bekerja, kemudian mereka berjalanjalan menghabiskan waktu senggang. Jalan yang mereka bangun panjangnya kira-kira $10 \mathrm{~km}$. Terdapat 30 orang BB yang mengerjakan pembangunan jalan tersebut. Untuk tempat tinggal mereka membuat barak atau camp (kemah) sebagai tempat tinggal sementara dengan atap dan dinding dari terpal. Mereka ialah orang-orang yang berasal dari Madura yang tinggal di Singkawang, Kalimantan Barat. Mereka umumnya berasal dari Kabupaten Sampang, di Pulau Madura. 
Sebanyak 30 orang BB sedang mengerjakan pembangunan jalan tersebut terdiri atas para orang tua dan orang muda. Dalam menghadapi ragam pekerjaan, mereka membagi tugas secara tegas. Untuk memecah batu besar diberikan kepada para orang tua, sebab tidak semua orang bisa memecah batu besar dengan "bodem" atau palu besar. Di samping itu, jika tidak mempunyai ketrampilan memecah batu, maka risikonya kaki atau badan bisa terkena bodem atau serpihan batu. Sedangkan mereka yang muda bertugas mengangkut dan menata batu laterit di atas jalan yang dibangun atau diperkeras. Upah per hari baik orang tua maupun orang muda sama. Saat itu diperoleh informasi bahwa sudah dua hari rombongan $B B$ pembangun jalan menganggur karena batu-batu laterit belum juga datang. Selama 2 hari menganggur itu ada BB yang main ke warung kopi di afdeling 3, ada yang berjalanjalan ke Meliau, ada pula yang sekedar tidurtiduran di bawah pohon sawit. Hal itu dilakukan karena barak dari terpal kalau kita berada di dalamnya di siang hari udaranya panas sekali. Lokasi proyek pembangunan jalan itu kira-kira 3 $\mathrm{km}$ dari perumahan afdeling 3 .

Salah satu BB yang ikut membangun jalan bernama Samurin yang berasal dari Sampang, Madura. Dia bersama rombongannya dipanggil dan diajak oleh Pak Kacung (kacung = thole) yang juga orang Madura, tetapi sudah lama tinggal dan menetap bersama dengan keluarganya di Singkawang, Kalbar. Pekerjaan utama Samurin, yaitu melakukan pengerasan jalan dengan batu split laterit dengan cara borongan sepanjang 10 $\mathrm{Km}$. Upah bisa dia terima apabila pekerjaan selesai dikerjakan. Besarnya upah bersih yang ia terima setelah dipotong bon hutang dan uang panjar. Setelah proyek pengerasan jalan di afdeling 3 selesai, Samurin akan pindah ke tempat lain untuk ikut proyek pengerasan jalan dengan batu laterit di Meliau. Jalan sepanjang $10 \mathrm{~km}$ yang akan diperkeras dengan batu laterit jika kondisinya lancar, maka bisa diselesaikan dalam waktu 8 hari kerja oleh 30 orang BB. Para BB ini untuk memenuhi kebutuhan makan dan minum 3 kali sehari mereka bon terlebih dulu. Jika setelah pekerjaan borongan pengerasan jalan itu selesai dalam 8 hari, maka upah mereka terima dengan terlebih dahulu dipotong bon makan dan minum 3 kali/hari.
BB lainnya yang turut membangun jalan, yaitu Pak Herman. Dia juga berasal dari Sampang Madura, tetapi dia telah lama tinggal di Singkawang, Kalimantan Barat. Namun, anak dan istrinya tinggal di Sampang, Madura. Para BB didatangkan dari Meliau oleh kontraktor bernama Pak Ajid untuk membangun jalan dengan melakukan pengerasan jalan tanah yang dilapisi dengan batu laterit. Pak Ajid mensubkontrakkan proyek pembangunan jalan tersebut kepada Pak Kacung. Peran Pak Kacung dalam hal ini sebagai ketua BB pengerjaan jalan.

Sebelum Herman menjadi BB ikut membangun jalan di Kalimantan Barat, ia pernah berpengalaman berjualan sate ayam di Medari, Sleman, Yogyakarta; Kebon Polo, Magelang, Jawa Tengah; dan di Temanggung, Jawa Tengah. Hasil dari berjualan sate ayam menurutnya lebih kecil jika dibandingkan penghasilan menjadi BB membangun jalan. Namun, menurutnya berjualan sate ayam bekerjanya lebih enak dan santai. Misalnya tidak pernah mendapat teguran dari pemborong serta tidak berpanas-panasan di tengah perkebunan sawit yang lokasinya jauh dari pemukiman penduduk dan jauh pula dengan warung tempat membeli kebutuhan sehari-hari.

\section{Latar Membangun J embatan}

Selain kelompok BB yang mengerjakan tapak, rumah, dan jalan di afdeling 3 masih terdapat satu kelompok BB lagi yang membangun jembatan. Empat orang BB yang sedang membangun jembatan cor tersebut pernah penulis wawancarai pada saat mereka istirahat di warung milik Pak Kaum. Mereka pergi ke warung Pak Kaum umumnya makan minum dan mengisi ulang telpon selulernya. Hal ini dilakukan karena di camp yang mereka dirikan di dekat proyek tidak ada aliran listrik. Jamhari, Mulyanto, Hasan, dan Rudi ialah nama-nama di antara para BB yang membangun jembatan di afdeling 3. Pimpinan yang mengajak mereka bekerja ke tempat ini bernama Pak Taufik.

Pak Taufik yang mengajak para BB membangun jembatan ini berasal dari Kabupaten Ketapang, Kalimantan Barat, sedangkan istrinya berasal dari Kabupaten Sanggau, Kalimantan Barat. Saat ini istri Pak Taufik dan anak-anaknya tinggal di Sanggau. Taufik mendapat pekerjaan borongan membangun jembatan dengan cara 
ngesub kontrak dari Pak Ameo. Jamhari, Rudi, dan Hasan merupakan BB etnis Melayu yang berasal dari Desa Balai Karangan, Kecamatan Sekayam, Kabupaten Sanggau yang bekerja membangun jembatan tersebut. Berbeda lagi dengan Mulyanto yang berasal dari suatu desa di Jawa Tengah (sebutan suatu desa orang Jawa yang berada di tengah-tengah antara kampung Dayak dan kampung Madura) di Kecamatan Sungai Ambawang, Kabupaten Kubu Raya. Orang tua Mulyanto adalah transmigran dari Blora, Jawa Tengah. Para BB tersebut umumnya mendapat informasi tentang adanya pekerjaan membangun jembatan di tempat itu berasal dari teman dengan memanfaatkan komunikasi lewat telpon seluler.

\section{Nilai Saling Percaya}

Berdasarkan empat latar yang telah dibahas di atas serta berpijak pada konsepsi nilai di muka, di dalam fenomena bekerja pada komunitas BB di perkebunan sawit Sungai Dekan terdapat beberapa nilai yang dapat ditarik simpulan. Pertama, yaitu nilai saling percaya. Dalam konteks perkebunan sawit "sesuatu yang seharusnya diinginkan" adalah adanya sikap saling percaya antara pemborong/mandor borong dengan para BB. Sebagai contoh dalam membangun rumah di afdeling 3, Suradi adalah mandor TU (tanam ulang) di afdeling 3 .

BB yang didatangkan oleh Suradi untuk membangun rumah di afdeling 3 jumlahnya pernah mencapai 28 orang. Pada waktu musim pembuatan tapak Suradi juga pernah mendatangkan sebanyak 60 orang BB. Bagi Suradi modal mendatangkan BB hanyalah telepon seluler untuk menghubungi teman atau relasinya di Jawa. Di samping itu, dengan modal kepercayaan pada orang lain merupakan sandaran dalam bekerja. Suradi sendiri pun belum pernah pergi ke Blora, Tulungagung, atau Ngapak di J awa yang menjadi daerah asal para BB. Pada suatu waktu pernah Suradi kena tipu. Suatu waktu para calon BB sudah diberi uang transport dari Jawa ke Kalbar. Namun yang terjadi para BB tersebut tidak ada yang datang di Kalbar, sehingga uangnya hilang. Pada lain waktu, Suradi telah berhasil mendatangkan BB dari Jawa ke kebun kelapa sawit di Singkawang. Namun yang terjadi dia tidak mendapat fee seperti yang dijanjikan oleh mitranya di Singkawang. Hal ini disebabkan mitra yang dimaksud saat itu menjadi asisten di kebun kelapa sawit setempat telah dipromosikan menjadi asisten kepala, dan ia pindah kerja ke tempat lain.

Nilai kepercayaan dalam bekerja juga bisa dilihat pada kasus lain berikut ini. Salah satu BB membuat tapak bernama Ndhole di hari-hari akhir penelitian ini menelpon penulis. Ia saat itu telah kembali ke Pulau Jawa. Menurut Ndhole, bahwa upah napak di afdeling 3 selama 1 bulan terakhir belum dibayar oleh Suradi. Dengan adanya kasus yang menimpanya ia kemudian menemui Bu Lastri untuk berembug. Bu Lastri merupakan istri Pak Parno di mana Ndole pernah menumpang tidur di keluarga itu pada saat bekerja sebagai BB di afdeling 3.

Dari rembug itu muncul sikap saling percaya antara Ndole dengan Bu Lastri yang sama-sama berasal dari Sragen, Jawa Tengah. Akhirnya Ndole hutang uang kepada Bu Lastri dengan kesepakatan bahwa upah selama 1 bulan yang belum dibayarkan oleh Suradi, nanti harus diberikan kepada Bu Lastri. Dalam kesempatan itu Ndole sekaligus juga meminta tolong kepada Bu Lastri agar nyaur bon-nya (membayar hutang) makanan dan rokok di warung milik Mbah Tikno jika upah napak telah diberikan oleh Suradi.

\section{Nilai Relasi Patron-Klien}

Nilai relasi patron-klien ini bisa dilihat pada kasus yang terjadi antara para BB dengan Suradi, Kacung, dan Taufik yang membawa mereka ke tempat bekerja di afdeling 3. Kasus lainnya, misalnya hubungan antara Suradi dengan pemilik proyek bernama Ajid, antara Taufik dengan Ameo, dan antara Kacung dengan Ajid. Untuk pekerjaan borong membangun rumah di afdeling 3 misalnya, Suradi mendapatkannya dengan ngesub kontrak pada Ajid, sedangkan kerja borong membuat tapak diperoleh Suradi dari perusahaan perkebunan melalui asisten afdeling, karena posisinya sebagai mandor tanam ulang. Taufik mendapat pekerjaan borongan membangun jembatan dengan cara ngesub kontrak kepada Ameo, sedangkan Pak Kacung mendapat pekerjaan borong membangun jalan dengan cara ngesub kontrak kepada Ajid. 
BB membuat tapak untuk replanting didatangkan oleh kontraktor tenaga kerja atau mandor borong. Di afdeling 3 yang biasa mendatangkan BB membuat tapak kuda dan BB membangun rumah adalah Suradi. Dalam proses mendatangkan BB guna membangun rumah, Suradi bekerja sama dengan mandor borong bernama Sutarno. Kata Suradi, jika bekerja di PTPN sebagai karyawan tetap itu enak, di samping mendapat gaji tiap bulan masih ditambah "premi", yaitu upah tambahan karena yang bersangkutan telah mencapai target dan masih mau meneruskan pekerjaan. Bagi yang rajin bekerja, "premi" yang diterimanya tiap bulan juga akan besar. Menurut Suradi, premi karyawan tetap yang bertugas memanen sawit dalam satu bulan bisa menerima 3 sampai 4 juta rupiah.

Para BB membuat tapak didatangkan oleh Suradi dan dibayar oleh Suradi setelah dana pembuatan tapak bisa dicairkan dari kantor perkebunan. Dalam hal pembangunan rumah agak beda. Para BB membangun rumah didatangkan oleh Suradi yang memberi upah Suradi apabila uang dari Ajid (kontraktor pemenang proyek) sudah dibayarkannya. Taufik akan membayarkan upah kepada para BB pembangunan jembatan apabila pekerjaan sudah selesai dan uang sudah diserahkan Ameo kepada Taufik. Begitu pula Kacung akan segera membayar para BB jika pekerjaan membangun jalan sudah selesai dan uang borongan pekerjaan tersebut telah diserahkan Ajid.

Dalam proses kerja secara borongan sebagaimana diungkap di atas terdapat fenomena hubungan patron dan klien, yaitu hubungan sinergi antara mandor borong/subkontraktor sebagai patron dengan BB sebagai klien atau anak buah yang membantu para mandor borong. Modal tersebut menurut Ahimsa-Putra (2007; 21) bahwa, “Dari berbagai kasus hubungan patron dan klien yang dikenal sebagai hubungan minawang, .....tampak relasi yang menguntungkan kedua belah pihak. Hubungan timbal balik, saling memberi dan menerima ini menguntungkan patron sebab dengan adanya pengikut-pengikut, sehingga patron tidak perlu menjalankan tugas atau pekerjaan yang dirasa tidak pantas dilakukannya". Klien juga diuntungkan karena klien mendapat jaminan ekonomi, keamanan, atau pun kehormatan dan status sosial.
Lebih lanjut Ahimsa-Putra (2007) mengatakan, bahwa “Hubungan patron-klien (patronclient relationship), patronase (patronage), clientelism, clientage, merupakan konsep-konsep yang sangat populer dalam kajian politik di tahuntahun 1960-1980an. Diawali dari beberapa etnografi yang ditulis oleh beberapa ahli antropologi yang melakukan penelitian di kawasan Amerika Selatan (Foster, 1961; 1963, dan Heath 1973), dll". Dalam konteks kerja secara borongan di perkebunan sawit ini sosok Suradi, Kacung, dan Taufik adalah tipe patron ketika mereka berada di area kerja borongan, karena mereka memiliki anak buah BB yang membantunya dalam kerja borongan. Relasi ini akan bergeser manakala Suradi, Taufik, dan Kacung berhubungan dengan Ajid dan Ameo yang menjadi pemenang tender proyek dan memiliki SPK (Surat Perintah Kerja) dan mensubkontrakkan proyek kepada mereka bertiga. Dalam konteks ini, Suradi, Taufik dan Kacung menjadi klien dan Ajid serta Ameo posisinya adalah patron.

Para BB memiliki keuntungan berupa pekerjaan dan upah kerja yang diberikan oleh para mandor borong atau subkontraktor yang membawa mereka ke afdeling 3. Sebaliknya para mandor borong atau para subkontraktor memiliki keuntungan dengan mengambil selisih biaya nilai borongan pekerjaan dari kontraktor dengan upah yang harus dibayarkan kepada para BB yang dia bawa. Begitu pula dengan kontraktor pemegang SPK juga memiliki keuntungan dalam berhubungan dengan para subkontraktor karena para kontraktor tidak perlu susah-susah bekerja, tetapi masih bisa mengambil selisih biaya sesuai kontrak proyek dengan biaya yang harus dia bayarkan kepada subkontraktor.

Nilai relasi patron-klien juga bisa dilihat pada peristiwa seorang BB membuat tapak (klien) yang meminta izin pada mandor borong (patron) untuk diperbolehkan menjadi BB membangun rumah. Seorang klien yang ingin pindah pekerjaan memiliki ketergantungan pada patron berupa ijin atau penolakan oleh patron. Munaji (brewok) yang menjadi BB membuat tapak pernah nembung atau minta izin pada Sutarno mandor borong dari Blora yang menjadi mitra kerja Suradi. Munaji mau ikut nglepo rumah di afdeling 3 yang sedang dibangun oleh para BB dari Blora karena ancak tapak Munaji sudah habis. 


\section{Nilai Religi}

Dalam pengertian di sini nilai religi adalah adanya keyakinan atas sikap batin tertentu yang bisa menjadi solusi terhadap permasalahan yang mengganggu keseimbangan berpikir dan keseimbangan hidup seseorang atau suatu keluarga atau suatu kelompok masyarakat. Dengan melakukan aktivitas tertentu yang diyakini bisa menghubungkan diri dengan sesuatu yang adi kodrati (Tuhan), orang atau kelompok orang akan merasakan beban hidupnya menjadi lebih ringan. Nilai religi dalam bekerja di perkebunan sawit ini bisa dilihat pada kasus yang terjadi pada BB membuat tapak bernama Sukir.

Pada awalnya Sukir yang berasal dari Blora Jawa Tengah datang ke Kalimantan Barat karena terpaksa, sebab menjadi buruh bangunan (tukang batu/laden tukang batu) di Pulau Jawa "hasil bersihnya" hanya Rp 20.000/hari. Dia ingin mencari pekerjaan yang upahnya lebih tinggi lagi, maka dia kemudian pergi merantau ke Kalbar naik kapal laut dari Semarang. Selama 2 hari di atas kapal laut dia tidak makan dan minum, dia menjalani laku prihatin, aktivitas itu dia lakukan karena hatinya sangat sedih dan menderita setelah ditipu orang hingga uangnya sejumlah $\mathrm{Rp}$ 65.000 .000 (enam puluh lima juta rupiah) hilang. Penipuan itu berawal ketika datang seseorang yang mengaku sanggup memasukkan anak perempuan Sukir untuk menjadi CPNS di Kabupaten Blora. Dalam bujuk rayunya orang itu mengaku memiliki hubungan dekat dengan Ketua DPRD Blora. Setelah terjadi kesepakatan ternyata anaknya Sukir yang lulusan SMA tidak lolos menjadi CPNS, padahal Sukir sudah menjual rumah, 3 ekor sapi, dan sawah. Istrinya Sukir hampir stress menyaksikan hartanya bablas dan anaknya tidak berhasil menjadi CPNS.

Dengan "suasana kebatinan" seperti itu Sukir yang pekerjaannya menjadi buruh bangunan (tukang batu) dengan hasil upah yang tidak mencukupi untuk kebutuhan sehari-hari, kemudian dia nekat mencari temannya yang sudah bekerja membuat tapak kuda di perkebunan kelapa sawit Kalimantan Barat. Sukir akhirnya bertemu dengan teman yang dia cari kemudian dia ikut bergabung membuat tapak di perkebunan sawit afdeling 3 pada tahun 2010 selama 6 bulan. Jika teringat peristiwa penipuan itu Sukir kadang merasa putus asa dan marah karena dia sudah melapor ke polisi dengan disertai bukti kuitansi penerimaan uang tetapi polisi tidak segera memproses kasus penipuan itu. Tetapi jika Sukir putus asa dan stress, maka anak-anaknya dan istrinya mau makan apa? Untung masih ada satu rumah lagi walau jelek dan tidak sebagus yang telah dia jual, yang bisa ditempati keluarganya.

Sukir pertama kali menjadi BB membuat tapak di perkebunan sawit Kalimantan Barat tahun 2010, saat itu dia bekerja membuat tapak selama 6 bulan kemudian dia pulang ke Blora. Pada tahun 2011 ini Sukir ditelpon oleh Suradi untuk segera datang ke Meliau lagi karena ada proyek napak (membuat tapak). Sukir pun segera datang. Saat ini sudah bulan ke-4 Sukir bekerja membuat tapak di afdeling 3. Setelah gajian di bulan Juli nanti dia ingin pulang ke Blora menyongsong Bulan Puasa (nyekar makam leluhur).

Dari kasus Sukir ini terlihat bahwa dengan menjalani "laku prihatin" selama di atas kapal laut dalam perjalanan dari Semarang menuju Kalimantan Barat ini dia berharap beban hidupnya menjadi lebih ringan. Pikirannya tidak lagi stress memikirkan musibah penipuan yang dialami keluarganya, dan dia juga berharap keinginannya mendapatkan pekerjaan yang lebih baik dari sekedar menjadi tukang batu bisa terkabul. Setelah berhasil menjadi BB membuat tapak di perkebunan sawit, seperti masyarakat Jawa pada umumnya yang merasa memiliki kewajiban moral merawat makam leluhur sebelum datangnya Bulan Puasa/Bulan Ramadhan, Sukir juga berniat pulang ke Blora untuk nyekar atau nyadran di makam leluhurnya pada Bulan Ruwah (Bulan Sya'ban). Nilai religi bisa menjadi media bagi kondisi kejiwaan yang mengalami kegalauan (anomie atau liminalitas) untuk kembali pada kondisi jiwa yang tenang. Nilai religi juga bisa menjadi media komunikasi antara diri (self) dengan para leluhur (others) yang sudah berada di tempat yang berbeda, tetapi masih diyakini memiliki ikatan batin.

\section{Nilai Ketekunan Bekerja}

Tekun adalah sebuah konsep yang maknanya adalah melakukan aktivitas secara berulang-ulang yang disertai usaha sungguh-sungguh untuk memperoleh sesuatu. Nilai ketekunan bekerja 
dalam hal ini adalah adanya gagasan bahwa dalam bekerja untuk mendapatkan sesuatu secara optimal, juga harus didasari oleh sikap dan perbuatan yang optimal pula. Sebab dalam bekerja mungkin saja orang akan bermalasmalasan atau "sak tekane" karena tiadanya harapan yang optimal dari proses bekerja. Nilai ketekunan bekerja bisa diperhatikan pada kasuskasus berikut ini. Dalam sehari biasanya Sukir mampu membuat 6 sampai 7 tapak kuda untuk replanting tanaman sawit. Jika tubuh sedang fit dan tanah mengandung pasir, sehingga mudah dicangkul maka dalam sehari dia bisa membuat 10 sampai 11 tapak kuda. Upah membuat tapak kuda adalah Rp 17.000 (tujuh belas ribu) untuk setiap tapak kuda. Jika dalam sehari Sukir bisa membuat 6 tapak kuda, maka upahnya adalah $6 x$ Rp $17.000=$ Rp102.000 per hari. Jika dalam sehari mampu membuat 11 tapak kuda, maka upahnya adalah $11 \times \operatorname{Rp} 17.000=\operatorname{Rp} 187.000$ per hari. Upah membuat tapak timbun lebih mahal, yaitu $R p$ 24.000,- tiap tapak timbun. Upah membuat tapak timbun lebih tinggi, karena pekerjaannya lebih berat, lebih banyak tanah yang harus dicangkul dan digeser. Jari-jari tapak kuda dan tapak timbun adalah 2,40 m. Biasanya karyawan tetap di PTPN dalam sehari hanya sanggup membuat 3 sampai 4 tapak kuda, seperti yang pernah dilakukan oleh Sularno di muka.

Kasus nilai ketekunan bekerja selanjutnya adalah yang dilakukan oleh Munaji. Dia biasanya dalam satu hari bisa membuat 6-7 tapak kuda. Selain menjadi BB tapak, dia pernah menjadi buruh bangunan di afdeling 3 . Dia juga pernah menjadi buruh bangunan di Semenanjung Malaysia secara ilegal karena paspor \& visanya sudah kadaluwarsa tetapi tidak dia diperpanjang lagi. Waktu ada razia oleh polisi Malaysia dia termasuk TKI yang ditangkap dan dikembalikan ke Indonesia melalui Dumai Riau, dengan menggunakan kapal. Munaji selalu merasa mujur sebab setiap kali setelah bayaran, uang itu dia kirim kepada istrinya di Ponorogo, sehingga uang itu tidak dirampas oleh polisi Malaysia. Sesampainya di Dumai Riau para TKI gelap ini dihadang oleh tekong (calo TKI) dan ditawari oleh tekong apakah mereka ingin pulang ke daerah asal atau kembali bekerja ke Malaysia? Munaji memilih kembali ke Malaysia, tetapi diharuskan membayar 1.500 RM (setara Rp
4.500.000) kepada tekong, yang disuruh membayar adalah toke (bos, patron) di Malaysia yang nantinya akan mencarikan pekerjaan. Setelah bekerja dan mendapat upah bekerja di Malaysia, utang Munaji 1.500 RM kepada toke tadi akan dia bayar. Beberapa saat kemudian Munaji kembali ke Indonesia dan pergi ke Kalimantan Barat menjadi buruh borong (BB) membangun rumah. Dia ditawari oleh Suradi untuk membuat tapak di kebun sawit afdeling 3, Munaji menyanggupi. Itulah awal mula Munaji bekerja membuat tapak di kebun sawit. Munaji menjadi BB dan dia bekerja jika ada perintah dari Suradi. Dia mendapat upah tiap bulan sesuai dengan jumlah tapak yang dibuat.

\section{Nilai Perlawanan Kultural}

Nilai perlawanan kultural pengertiannya, yaitu adanya perlawanan yang tidak secara langsung dilakukan oleh orang kecil terhadap orang besar, rakyat terhadap penguasa, atau orang pinggiran terhadap sistem yang telah mengalahkan mereka. Nilai perlawanan kultural merujuk pada gagasannya Scott (2000) tentang senjata yang dimiliki oleh orang-orang kalah dalam studi etnografis tentang petani yang dia lakukan di Kampung Sedaka, Kedah, Malaysia. Menurut Scott (2000) bahwa senjata yang biasa dimiliki dan digunakan oleh kelas yang relatif tidak berdaya dan selalu kalah adalah; memperlambat pekerjaan, bersifat pura-pura, melarikan diri, purapura memenuhi permohonan, pencurian, purapura tidak tahu, menjatuhkan nama baik orang, pembakaran, penyabotan, dan sebagainya. Bentuk-bentuk pertarungan kelas ala Brecht dan Schweik ini memiliki aspek-aspek tertentu yang sama. Mereka hampir tidak membutuhkan koordinasi atau perencanaan, menggunakan pemahaman implisit serta jaringan informal, sering mengambil bentuk mengurus diri sendiri, dan mereka secara khas menghindari konfrontasi simbolis yang langsung dengan kekuasaan.

Nilai perlawanan kultural juga bisa dilihat pada kasus berikut ini. Pada waktu penulis sedang melakukan observasi di afdeling 3, penulis menyaksikan Suradi mengajak Munaji dan Ndhole untuk ikut bekerja "ngecor" bangunan perluasan Pabrik Kelapa Sawit di Meliau. Munaji terlihat diam saja. Munaji sebenarnya ingin menolak ajakan 
Suradi yang juga telah mengajaknya untuk bekerja menjadi BB membuat tapak, akan tetapi dia tidak berani mengungkapkan keinginannya itu dengan kata-kata. Dia menolak ajakan Suradi dengan cara diam tanpa kata-kata. Berbeda dengan yang dilakukan Ndhole, dia menolak ajakan Suradi dengan kata-kata yang maknanya bias. Sambil bermain catur melawan Pindo, Ndole semayan (menolak agar rencana ke Meliau diundur) kepada Suradi dengan mengatakan “nanti kalau kerja membuat tapak sudah selesai saja, agar hitung-hitungan bayaran membuat tapak lebih gampang". Pada dasarnya sikap Munaji dengan Ndhole adalah sama saja, yaitu menolak kemauan Suradi yang mengajak mereka berdua untuk bekerja menjadi BB membangun perluasan bangunan pengolahan kelapa sawit di Gunung Meliau. Mereka berdua sungkan atau tidak berani menolak secara terbuka karena Suradi adalah orang yang mempekerjakan mereka berdua menjadi BB membuat tapak di afdeling 3. Pada akhirnya Suradi memang tidak memaksa mereka berdua untuk pergi ke Meliau ngecor pabrik.

Mandor borong atau kontraktor BB yang mempekerjakan BB napak sebenarnya mendapat premi (keuntungan tambahan) dari PTPN XIII sebesar Rp 1.200 (seribu dua ratus rupiah) untuk tiap satu tapak yang dibuat oleh BB yang dia bawa. Pengalaman Ndhole waktu bekerja napak di kebun sawit Gunung Meliau afdeling 3 (masih bagian dari PTPN XIII juga), Ndhole pernah membawa 5 teman BB membuat tapak kemudian Ndhole mendapat fee $\mathrm{Rp} 1.200$,- untuk setiap tapak yang telah dibuat oleh 5 orang BB yang dia bawa tersebut. Jika 5 orang BB teman Ndhole membuat 1.000 tapak, maka $1.000 \times \mathrm{Rp} 1.200=$ Rp 1.200.000 diterima oleh Ndhole sebagai premi atau fee pembawa BB. Jadi mandor borong atau kontraktor BB yang mempekerjakan dirinya pasti mendapatkan fee atau premi dari setiap tapak yang dibuat oleh Ndhole dan BB lain.

Menurut Ndhole jika hari kemarin sudah ada "kontrolan" pembuatan tapak oleh mandor Paeran, maka besok Ndhole akan membuat tapak yang lebih kecil-kecil (diameter lingkaran tapak lebih kecil, kurang dari 2,40 m) saja. Dengan membuat tapak yang lebih kecil dari ukuran sebenarnya artinya pekerjaan menjadi lebih mudah dan lebih cepat selesai. Dia akan berbuat curang karena dia telah diakali, kata Ndhole “Ngakali ya harus ganti diakali". Menurut Ndhole harga atau upah setiap satu tapak aslinya adalah Rp 50.000 (lima puluh ribu) sampai Rp 60.000 (enam puluh ribu), akan tetapi upah yang dibayarkan kepada BB napak seperti dirinya hanya Rp 17.000 (tujuh belas ribu rupiah) tiap satu tapak kuda. Ndhole tahu hal itu langsung dari mandor borong waktu Ndole bekerja membuat tapak di kebun sawit Gunung Meliau. Kata si mandor borong, potongan upah itu dibagi-bagi untuk manajer, askep, asisten, krani, dan mandor.

\section{Nilai Kebersamaan}

Berada jauh dari anak dan istri serta keluarga yang lain dalam bekerja menjadi BB di afdeling 3 adalah sebuah pilihan yang berat. Apabila berada di tengah-tengah angota keluarga di rumah sendiri, maka banyak hal yang bisa dilakukan untuk berbagi dengan anak-anak dan istri atau anggota keluarga yang lain. Pekerjaan rumah tangga seperti memasak, mencuci pakaian, membersihkan rumah dan pekerangan, merawat ketika sakit atau melakukan kewajiban warga masyarakat seperti mendatangi undangan pernikahan atau selamatan menjadi mustahil dilakukan ketika sedang bekerja di rantau menjadi BB. Berbagi dalam senang dan susah pun tidak bisa dilakukan dengan anggota keluarga. Sesuatu yang bisa dilakukan adalah dengan sesama teman BB yang bersama-sama berada lokasi afdeling 3 . Hidup dijalani dengan suasana kebersamaan menjadi kondisi yang seharusnya dijalani oleh para BB. Kasus adanya nilai kebersamaan pada komunitas BB adalah sebagai berikut.

Suatu ketika penulis berjumpa dengan Pak Sapi'i, Joni, dan Ahmad Sahid. Ahmad Sahid umurnya 12 tahun, dia anggota BB paling muda. Mereka adalah bagian dari rombongan BB yang membangun jalan di afdeling 3. Mereka datang berombongan minum kopi, kuku bima, teh atau minuman lain di warung Pak Kaum, ada juga yang mengisi ulang stroom batere handphone karena di camp proyek tidak ada listrik. Mereka juga berbelanja telur ayam yang akan mereka jadikan lauk untuk makan nasi bersama di camp, mencari bahan makanan pun bersama-sama.

Kebersamaan juga terdapat pada kehidupan 3 orang BB membuat tapak, yaitu Munaji, Sukir, 
dan Sarjan yang menginap di rumah kosong afdeling 3. Mereka masak nasi bersama untuk dimakan bersama pula, sedangkan 8 orang BB membangun rumah yang menginap di afdeling 3 di sebelah rumah Suwaji, yang memasak setiap hari satu orang dan dilakukan secara bergiliran. Ada 8 orang BB membangun 3 rumah tembok di Afdeling 3. Mereka makan secara bersama-sama pula. Begitu juga untuk minum kopi, satu orang memasak kopi di dalam satu ceret, kemudian diminum bersama-sama.

BB membangun rumah itu semuanya bisa menjadi tukang, baik tukang batu, tukang kayu, tukang plester, atau anyam besi cor. Dengan kata lain, mereka adalah tukang yang serba bisa. Mengaduk adonan semen pun dilakukan oleh tukang yang bersangkutan tanpa dilayani oleh laden tukang. Di rumah tempat mereka menginap tersedia beras dalam karung dan juga sayuran maupun bahan untuk lauk. Mereka masak secara bergantian setiap harinya untuk dimakan bersama-sama. Mereka semua adalah rombongan BB yang datang dari Klopoduwur, Banjarejo, Blora, Jawa Tengah. BB yang bekerja di afdeling 4 lebih banyak dari pada di afdeling 3 karena untuk mengimbangi tahapan pembangunan rumah di afdeling 3 yang hampir selesai sehingga nantinya rumah-rumah itu bisa selesai, secara bersamaan, kemudian pulang secara bersamaan ke Jawa atau bergerak bersama-sama untuk membangun proyek di tempat lain.

\section{Simpulan dan Saran Simpulan}

Dari paparan di muka selanjutnya dapat diambil benang merah berupa simpulan. Dalam sistem kerja borong biasanya perusahaan tidak berhubungan langsung dengan buruh borong (BB). Para BB biasanya selama bekerja bertempat tinggal di tenda-tenda ikut pemborong yang membawa mereka atau menumpang di rumahrumah milik perkebunan. Perusahaan perkebunan lebih senang dengan sistem kerja borongan karena buruh tidak banyak menuntut. Karyawan tetap yang dijamin hak-haknya oleh UU malah tidak disenangi oleh perusahaan karena dianggap banyak tuntutan. BB adalah tenaga kerja yang secara administrasi tidak berada dalam area birokrasi perkebunan seperti halnya karyawan tetap, karyawan PKWT, atau BL.

Secara taksonomis terdapat beberapa jenis pekerjaan BB yang identik dengan daerah asal para BB. Pekerjaan membuat tapak dalam proses peremajaan tanaman kelapa sawit (replanting) dilakukan oleh BB yang berasal dari Pulau Jawa (Ponorogo, Sragen, Blora, dan Klaten). Ada juga di antara mereka yang berasal dari warga transmigran Sungai Radak, akan tetapi daerah transmigran itu warganya juga berasal dari Pulau Jawa. Pekerjaan membuat bangunan rumah dilakukan oleh BB yang berasal dari Jawa juga (Blora dan Ponorogo). Selanjutnya pekerjaan membangun jalan dikerjakan oleh BB yang berasal dari Madura (Sampang). Pekerjaan membangun jembatan dikerjakan oleh BB dari Desa Balai Karangan Kabupaten Sanggau dan dari Desa Jawa Tengah di Kabupaten Kubu Raya.

Setelah dilakukan penelitian mendalam selama satu bulan kemudian bisa terungkap adanya 6 nilai bekerja pada komunitas BB. Nilainilai bekerja tersebut adalah; nilai saling percaya, nilai relasi patron-klien, nilai religi, nilai ketekunan bekerja, nilai perlawanan kultural, dan nilai kebersamaan.

\section{Saran}

Tujuan riset ini yaitu ingin mengetahui tentang nilai-nilai bekerja pada komunitas BB di perkebunan kelapa sawit, bahwa upah (wage) bukan satu-satunya aspek penting bagi orang bekerja. Upah memang penting dalam bekerja, akan tetapi nilai-nilai bekerja juga penting.

Nilai-nilai bekerja bisa menjadi aspek penting dalam memahami fenomena orang bekerja, bisa juga digunakan untuk memahami karakter masyarakat secara luas, sehingga tidak akan salah dalam membangun relasi antara pekerja dengan perusahaan tempat bekerja. Konflik sosial yang sering terjadi di Kalimantan Barat antara masyarakat lokal dengan masyarakat pendatang bisa diantisipasi dengan adanya saling memahami nilai-nilai budaya masyarakat yang berbeda. Dalam hubungan sosial bisa terjadi konflik yang kadang berawal dari adanya perbedaan nilai budaya, atau tidak adanya saling memahami nilai budaya antar masyarakat yang saling berhubungan. 


\section{Pustaka Acuan}

Ahimsa-Putra, Heddy Shri. 2007. Patron \& Klien di Sulawesi Selatan Sebuah Kajian Fungsional-Struktural. Yogyakarta: Kepel Press.

Ahimsa-Putra, Heddy Shri. 2009. Nilai-nilai Budaya Politik dalam Mitos To-Manurung di Sulawesi Selatan. Artikel IImiah.

Hagul, Peter, Chris Manning, dan Masri Singarimbun. 1989. "Penentuan Variabel Penelitian dan Hubungan Antar Variabel". Dalam Masri Singarimbun \& Sofian Effendi, Metode Penelitan Survei. Jakarta: LP3ES.

Marzali, Amri. 2005. Antropologi \& Pembangunan Indonesia. Jakarta: Kencana.

Personalia Umum \& Humas PTPN XIII Kebun Sungai Dekan. 2011. Pedoman Bagi Karyawan Peserta Pelatihan Administrasi Bidang Admi Kepersonaliaan dan Keuangan Umum.

Scott, James C. 2000. Senjatanya Orang-orang yang Kalah Bentuk-bentuk Perlawanan Sehari-hari Kaum Tani. Jakarta: Yayasan Obor Indonesia.

Strauss, Anselm \& Juliet Corbin. 2003. Dasar-dasar Penelitian Kualitatif Tatalangkah dan Teknik-teknik Teoritisasi Data. Yogyakarta: Pustaka Pelajar.

Syahrizal. 2006. Strategi Buruh Perkebunan Mengatasi Kemiskinan, Studi di Perkebunan Teh PT Mitra Kerinci Sumatera Barat. Padang: Andalah University Press.

Wallman, Sandra. 1979. Social Anthropology of Work. London: Academic Press.

Zurinani, Siti. 2010. Karyawan dan Buruh Lepas: Sketsa Pekerja Perempuan di Perkebunan Kelapa Sawit Sei Dekan Afdeling Satu. TPL Meliau 2010. http// www.ruraleconomics.fib.ugm.ac.id (diunduh: 1-4-2011). 